\title{
INTRODUCTION
}

\section{The Presence of the Past in the Era of the Nation-State}

\author{
Nicolas Argenti
}

\begin{abstract}
With contributions from several of the Balkan countries that once were united under the aegis of the Ottoman Empire, this special issue proposes new theoretical approaches to the experience and transmission of the past through time. All of the articles in this issue explore themes to do with the transmission of collective memories of post-Ottoman state formation and the malaise associated with a contemporary epoch that, echoing late modernity, we might term 'late nationalism'. This introductory article examines the several manifestations of this general phenomenon under the rubric of post-Ottoman topologies, suggesting that where history creates a fixed, empiricist record of the past, topologies denote the flux of collective memory in its multiple and mutable incarnations across time.
\end{abstract}

Keywords: Balkans, collective memory, melancholy, nostalgia, oikoumenê, post-Ottomanism, temporality, trauma

The melancholy of this dying culture was all around us. Great as the desire to Westernise and modernise may have been, the more desperate wish, it seemed, was to be rid of all the bitter memories of the fallen empire: rather as a spurned lover throws away his lost beloved's clothes, possessions and photographs. But as nothing, Western or local, came to fill the void, the great drive to Westernise amounted mostly to the erasure of the past. (Pamuk 2005: 27)

The Ottoman world was plural-religiously, culturally, linguistically, and legally, with members of the millets or castes within the empire subject to different regimes of taxation, dress code, legal rights, and obligations-but it was by the same token a unified social and political space in which Christians and Jews as well as Muslims could thrive as traders and professionals and could ascend to the highest levels of political authority and influence. The demise of the Ottoman Empire in the nationalist wars of the early twentieth century gave rise to a 
multiplicity of autonomous nation-states defined by their ethnicity in a forced movement of peoples the likes of which the world had never seen before. This special issue examines how individual and collective memories, affective states, and embodied experience are born from episodes of rapid social transformation, crisis, and political violence in the transition from an ethnically and culturally plural empire to a congeries of nation-states defined by nationalist ideologies predicated on the realization of ethnic and religious homogeneity.

\section{Space without Places, Time without Duration: Temporalities of Culture/Cultures of Temporality}

Maria Couroucli (2012: 1-2) has recently referred to the newly nationalized, "monocultural and monochromatic societies" of the Eastern Mediterranean as a "post-Ottoman space" in which religious pluralism gave way in the twentieth century to nationalist cultural homogeneity in the image of Western nationstates. The term 'post-Ottoman' as we use it here is intended to question the nationalist assumptions that drove the fracturing of the Ottoman Empire and the dissemination of the modernist ideal of the ethnically pure and sovereign nation-state. To adopt a post-Ottoman perspective is to ask what the loss of Ottoman identity as a supra-ethnic affiliation has entailed and how the violent ruptures occasioned by the collapse of the empire live on in contemporary social formations. In doing so, the articles in this special issue question the applicability of dominant models of linear time, revealing that peoples of the post-Ottoman world do not always experience their relationship to the historical transformations they have witnessed in a unilinear chronological fashion, as the Time of the State would have it, with the beginning of political time marked (and commemorated annually) by the birth of the sovereign nation in the violent destruction of an inevitably derided original state of ethno-religious and cultural pluralism. This is not to suggest that post-Ottomanism is a form of collective social atavism, nor does it entail an idealization of the Ottoman Empire in terms of a Rousseauesque prelapsarian Eden of uninterrupted equality and peace. ${ }^{1}$ Nationalist historiographies have nonetheless focused on the breakers and white caps of historical crises while ignoring the underlying tides of intercommunality that bound plural communities and millets together across linguistic and religious divisions for centuries in the empire (Albera and Couroucli 2012; Doumanis 2013; Theodossopoulos 2006).

In the decades following the Greco-Turkish War of 1919-1922 and the forced exchange of populations, the Anatolian and Pontian Greeks, who lost everything in the splintering of a plural empire into a grouping of ethnically purified nations, remembered their Muslim neighbors not with rancor and bitterness but as friends and community members with whom they had shared their day-today existence (Hirschon 1998, 2007). If the children and grandchildren of the original victims of the exchange of populations refer to themselves to this day as refugees (prosfighes), we must face the fact that the unilinear, historiographical time of the nation is confronted everywhere in the post-Ottoman state by the 
absence of a collective experience of time that would afford distance and with it the safety and reassurance that the ante-national past can be definitively isolated from the present. As Sarah Green (2010: 267) has astutely observed, the transition from an "Ottoman order of things" to a "national order of things" implied a connection with the past as much as a break from it. ${ }^{2}$

The workshop that gave birth to this publication, part of the Balkan Futures series of the British Schools at Athens and Ankara, was entitled "Balkan Topologies," and one may wonder why the title of this special issue now uses "Post-Ottoman” instead of “Balkan." Maria Todorova $(2004,2009)$ and Dimitris Tziovas (2003) have both delineated the associations of the term 'Balkan' with long-standing notions of 'Balkan mentality' and 'Balkan myths', including the myth of the '500-year Turkish yoke'. They point out that these stereotypes all stem from and say more about the Western preoccupation with the militant nationalisms of this region than they do about the peoples and places within it. The Orientalist trope of a 'Balkan mentality' supplants the complex realities of international politics at the fall of the Ottoman Empire with the myth of a purely local, nationalist belligerence that nevertheless is meant to typify and unite a whole region in a putative predisposition to animosity. Rather than dwell on the nationalist rejection of Turkish cultural heritage, this special issue examines not the power but the poverty of nationalistic fervor, highlighting the counter-currents with which it is confronted everywhere. It exposes the aporias that a national order of things has hollowed out of bodies of collective memory in the drive to construct temporally and territorially bounded histories, while exploring what lies buried and encrypted in the drive to demonize the Ottoman past. Shunning the myth of Balkan belligerence, the articles in this issue bear witness to the presence of a loss.

The post-Ottoman nation-state-in its Balkan incarnation-has made of its birth a cause for celebration, but its annual commemorations perpetually return the nation to the moment of its violent origins. The state recalls in public celebration and in formal education moments of official history that its citizens may privately remember with conflicting emotions of sadness, anxiety, guilt, loss, and melancholy as much as with patriotic joy (Bryant 2015; Doumanis 2013; Mills 2006, 2010; Navaro-Yashin 2012; Neyzi 2008). The post-Ottoman condition records the moment when the fanfare of the annual parades and the fireworks has ended, when the minorities marginalized by national discourses quietly remember the violence of the birth of the nation and face the loss of the plural forms of identity that had preceded it. To the extent that the post-Ottoman condition entails memory, it clutches at the memory of a loss. In memory of absence, post-Ottomanism marks the struggle against the absence of memory.

Albeit a geographically and demographically delimited phenomenon, postOttomanism also illustrates features of the human condition in late modernity and what we might term 'late nationalism' more generally. Post-Ottomanism reflects a global aspect of the nationalist era in which apparently discarded and long-forgotten political formations and their attendant affective registers seem uncannily to rise again as the integrity and supposed timelessness of national identities are weakened from above by neo-liberal world markets, sovereign 
debt crises, supra-state organizations, practices of terror and of counter-terror, and the abandonment of Enlightenment ideals of human rights and equality, and from below by virulent micro-nationalisms, widespread disenchantment with the unraveling of the nationalist project, and-more promisingly-resurgent awareness of pluralist forms of identity. The post-Ottoman condition is not an elitist nostalgia for the lost spoils of empire felt by the descendants of those in the metropolis who once enjoyed its fruits (Bissell 2005; Mills 2006, 2010; Stoler 2008); rather, it is a memory of loss born of the contemporary disappointment of those disaffected, marginalized, or unheard by the national project. Its affective dimension takes the form of an unvoiced mourning for what the monolithic nation-state that supplanted the great plural metropolises after the revolution was meant to have been but never became. At the grass roots, in the diasporas, and in the refugee settlements, post-Ottomanism is the genius loci of a regret in part for a lost past, but also for an absent present. In this sense, guarding the memory of a pre-national(ist) belle époque, or tempo doeloe (which in some places and times existed and in some cases was constructed post facto) in the face of the ethnicization of the nation and the state-sponsored demonization of difference takes on a critical political dimension in the present.

While evolutionary theories of social development have been left behind by the discipline, anthropology has nonetheless inherited from Enlightenment thinking a teleological model of political formation in which the nation-state is the natural endpoint of a universal process of state formation. Hobbes's state of nature-in which 'man is a wolf to man' (cf. Agamben 1998: 105-107) and the loss of freedom entailed in citizenship is necessary for human security-was not to him an abstract notion, but contemporary reality demonstrated by the newly discovered savages of America. Montesquieu-at first implicitly in Persian Letters ([1721] 1973) and then explicitly in The Spirit of the Laws ([1748] 1989)was also thinking of particular places when he identified the state of despotism, including the Ottoman Empire. But Montesquieu was not using the Ottoman Empire in a reified manner as the Orientalist Other to a civilized Europe: Montesquieu's Levant was not Hobbes's America. More subtly, Ottoman despotism encoded the potential for the abuse of power by the king of France: far from being distant and exotic, it was near at hand and familiar but hidden and unrecognized. Apparently applied as it is to a range of places and to peoples over an indefinite time-scale, Althusser (1972: 78) derides Montesquieu's despotism as a category that "lacks any social space," on the one hand, and historical duration, on the other: "Space without places, time without duration" (ibid.). ${ }^{3}$ But above and beyond his critique, Althusser may have been unknowingly prescient in his intended slight: far from being chimerical, such placeless spaces and recursive temporalities would become all too real in the post-Ottoman world.

Montesquieu ([1748] 1989) and Rousseau (1973) (and Rousseau's disciple Karl Marx) bequeathed to Durkheim ([1892] 1960), Lévi-Strauss (1952), and Sahlins (1972) the idea of state formation as an irreversible linear progression through increasingly hierarchical forms of domination and the notion of contemporary small-scale egalitarian societies as examples of the distant past of the Western world. Michael Herzfeld (1986) has delineated the Greek 
variant of this theory, which required nineteenth- and early-twentieth-century folklorists to cast the five centuries of Ottoman suzerainty as a state of arrested development and the present as a return to a classical past that simultaneously represented a new state of national efflorescence. But is the nation-state a natural endpoint of political development? Was the Ottoman Empire adequately accounted for as a state of despotism that represented a vestigial throwback to the tumultuous birth of social and political life? The post-Ottoman state is never without a foundational myth of origin referring to Ottoman oppression, corruption, exploitation, weakness, or inefficiency, and it follows Enlightenment thinking in placing the nationalist project at the apex of its civilizing mission. But the collective memory and the lived experience of the post-Ottoman sphere also encompass the wars, the massacres, the displacements, the crises, and the multiple failures of the nation-state. While official national memory is a memory of Ottoman failure and of national glory, post-Ottomanism is not a historical memory of Ottoman grandeur or glory. It does not claim the territory of Ottomanism. Rather, it haunts the lived experience of the failures of nationalist projects: space without places.

The revolutionary Greeks of the eighteenth and nineteenth centuries propagated Montesquieu's and Rousseau's ideas, such as when the Chiot patriot Adamantios Korais declared in his autobiography that to him "'Turk' and 'wild beast' were synonymous” (Clogg 1992: 3). But this view represents an intellectual and a political construct wedded to the war of independence that is not representative of the lived experience of the majority of Greeks under Ottoman rule, many of whom expressed more anxiety regarding the religious incursions of the Catholics in the empire than they did hatred for Muslim overlords. ${ }^{4}$ Indeed, Christians did not think of themselves as 'Greek' in the Ottoman Empire. The tradition of Hellenic continuity had yet to be invented, and people moved with relative freedom between religious, national, and ethnic categories (Barkey 2008: 21; Herzfeld 1986; Smyrnelis 2005). Be that as it may, postOttomanism refers not to a romantic attachment to a longed-for Ottoman past, but rather to the loss that the violence of the end of the empire entailed for so many. The loss of home, family, community, and property was accompanied by displacement, dispersal, exile, and the necessity to celebrate all of these injuries as gains for a nascent state to which people now had to find a way of belonging. When the state is relatively strong and enjoying a period of legitimacy, it is possible to accommodate this conflicted identity, but when it is in crisis and losing legitimacy, the foundational sacrifices that had been made are harder to hide and easier to mobilize, and the post-Ottoman condition becomes more acute.

It was by means of the mass forced movement of peoples, of pogroms and massacres, of religious persecution, and of wars and acts of para-statal violence that the states of the post-Ottoman sphere were able to secure ethno-nationalist sovereignty. After the wars, the quotidian structural violence engendered by the shortcomings of the nationalist project resurrects from oblivion the violence that accompanied the formation of the state. Current upheavals fold time back upon itself in crashing waves that throw the settled sands of history from the silent and darkened depths back onto the shores of cultural consciousness. 
In an irony of which the Young Turks may have been only partially conscious, the nationalist ideology that underpinned their revolutionary program was borrowed from Western models originally inspired by ancient Greek ideals of the oikoumenê. Originally denoting inhabited land as opposed to desert, the oikoumenê gradually came to designate territories inhabited by Greeks and later was restricted to the Christian dominions and people of the Roman and Byzantine empires (Brunet et al. 1992: 166). The oikoumenê eventually found a place in Western political ideology as a myth of state according to which a group of people were primordially suited to a landscape that they had inhabited since time immemorial. In this vision, the cradle of nature nurtured the infant of culture as much as culture nurtured nature (J. Berque 1970). The Ottoman Empire is remarkable for having uncoupled the essentialized relationship linking ethno-religiously defined peoples to places.

There is a second meaning to oikoumenê, however, whereby Ottoman cosmopolitanism can be described in contradistinction to European nationalism. Igor Kopytoff (1981) and Jean-Pierre Warnier (1985, 2014) reworked the term to describe the complex process by means of which a congeries of culturally distinct peoples nevertheless could form an interdependent social whole in the Grassfields of Cameroon. Sidney Mintz (1996), building on Kopytoff (1981) and Kroeber (1946), used the term in this reconstructed sense to refer to the confluence of peoples in the West Indies as a result of the upheavals of the slave trade. ${ }^{5}$ Like the West Indies, the Ottoman Empire was always too plural to be a 'culture area', and yet whatever their cultural background might have been, neighbors from different millets in the villages, towns, and cities of the empire were made much more alike than they were different from one another. They were, as Boas's mentor Ratzel put it when he borrowed the concept from its classical context, all part of "a great historic unit” (cited in Mintz 1996: 293) — one in which newcomers (and the living are all newcomers to the landscape created by the dwelling of previous generations) could be enfolded together with the dead in a temporal continuum (Green 2010: 270; Ingold 1993). A sense of shared existence between neighbors of different cultural and religious backgrounds characterized the peace that reigned over Anatolia for so much of the Ottoman Empire. In its quest for a monocultural, monolingual, and ethnically homogeneous state, post-Ottoman nation building has had to obliterate the uneventful memory of this intercommunal landscape of peace, "the homeland of our thoughts" (Merleau-Ponty 1962: 26).

Instead, the post-Ottoman state celebrated the violence committed and mourned the violence suffered in the rupture with the Ottoman past. The foundational pogroms and massacres of the Greek War of Independence, the Balkan Wars, and World War I; the Armenian genocide (see von Bieberstein, this issue); and the mass forced movement of peoples throughout Anatolia, the Balkans, Caucasus, Crimea, East Thrace, and the Mediterranean (Toynbee 1922) were not in this case so much 'things hidden since the foundation of the world' (Girard 1987) as the things that by their commemoration constituted the world. These cataclysmic events are nurtured in revanchist memories by the nascent states that divided the empire. While its foundational violence is engraved upon the 
memory of the post-Ottoman state, the state is amnestic about the centuries of peace enjoyed by the peoples of the Ottoman Empire. The storms of official memory-Fernand Braudel's ([1949] 1972: 21) surface disturbances of historyare belied by the silent pull of the sempiternal tides, the routines and habits of centuries of intercommunal living (Doumanis 2013: 3). No longer acceptable to official memory, these centuries of peace still form part of the inheritance of the refugees and their descendants. In other cases, it is not lost neighborliness, religious plurality, and cultural cosmopolitanism that form bodies of countermemory, but the unconscious pull of unmourned deaths and separations experienced in the pogroms of the past (Bryant 2010; Mills 2006, 2010; Rey 2008). In their immersion beneath official discourse and sanctioned emotion, memories of lost unity or of the desolation born of intercommunal violence take hold at times as nostalgia, but at other times as melancholia (Navaro-Yashin 2012).

Not amenable to the progressivist unilinear temporalities of the post-Ottoman state, this melancholic legacy keeps watch over silenced memories of pluralist ideologies that remain alien to the ethno-nationalist project. In his delineation of collective memory, Halbwachs (1992) demonstrates that memories not shared cannot be memories at all, but represent a ghost species of individual human experience doomed to pass into oblivion. The melancholia of post-Ottomanism may not be constituted by memories of specific historical events, but that is not to say that it is not a form of collective memory, or that the Ottoman past is no longer an active social force. Where the historicist paradigm sees the empirical past, post-Ottomanism attests to the enduring presence of what was lost, questioning monolithic models of chronological time.

In a work devoted to the melancholy provoked by his native city of Istanbul, Orhan Pamuk (2005) moves from observations of a personal nature, regarding the losses and sorrows suffered in his childhood and by his family, to the sense of end-of-empire loss that the city's crumbling Ottoman architecture embodies and exudes. In this movement from a purely private to a public melancholia, Pamuk identifies the collective aspect of hüzün, the Turkish term for melancholy: "Now we begin to understand hüzün as, not the melancholy of a solitary person, but the black mood shared by millions of people together. What I am trying to explain is the hüzün of an entire city, of Istanbul” (ibid.: 83). The hüzün of Istanbul, Pamuk tells us, is akin to the tristesse of South America in Lévi-Strauss's Triste Tropiques. As he puts it: “Tristesse is not a pain that affects a solitary individual; hüzün and tristesse both suggest a communal feeling, an atmosphere and a culture shared by millions" (ibid.: 90). In the end, the only protection from hüzün available to Istanbulites is to forget about the past, so that "[h]istory becomes a word with no meaning" (ibid.: 92). Just as Halbwachs's memory is collective, so is Pamuk's forgetting a joint project of the city's multitudes. The appeal to oblivion for protection against the pain of memory, however, can only be a Pyrrhic victory. Routing chronology at the cost of a headlong dash into chronicity, it fells the fully chronological dimension of time only to be haunted by the eternal return of its stunted shadow: the chronic.

In an article on the memories of Istanbul shared by the erstwhile activists of the left who lived through the repression of the 1980 coup d'état known as 
12 Eylül (12 September), Christopher Houston (2015) similarly moves from the individual to the collective, tracing the means by which the recently inaugurated Museum of Shame allows for the agglomeration of a myriad of personal traumas to be collectively elicited and reified in a collection of objects that provide a locus for the silenced memories of a stillborn socialist incarnation of the city. In the Museum of Shame, revolutionary Istanbul lives 'only in memory', but in a form of collective memory that has been projected onto the fabric of the city in which it persists up to the present. In its new memorial incarnation, a collective disillusionment-not only with a defeated and discredited communism, but also with the nationalist Kemalism that provided the raison d'être of the state-is made part of the affective present/presence of the city.

Post-Ottoman time marks the limit of models of temporality founded upon the premise of a linear chronology. In testifying to an experience of the affective half-life of political violence (remembered not as glory of the state or as culpability of the opponent, but simply as loss) as well as of uneventful coexistence, it challenges the central operative principle of Western historicity: that the past is distant and ever-receding. Because the majority of studies of collective memory in recent years have been studies of political violence, social scientists-influenced by literary theorists-have turned to science and sought to highlight the particular forms of suffering engendered by war with reference to the psychological category of trauma and the psychiatric symptomatology of post-traumatic stress disorder. ${ }^{6}$

Leaving aside the problem of universalization and the consequent erasure of context and history implicit in the trauma discourse (Argenti 2007, 2016; Argenti and Schramm 2010; Broch-Due 2016; Fassin and Rechtman 2009; Hacking 1995; Lewis 2013; Leys 2000; Young 1995), the key point for our current discussion is that trauma is said to break the linearity of psychic time, introducing to it a circularity or short circuit that is the root of the morbidity of the syndrome. The role of the therapist is to interrupt this circularity and to reestablish the linear continuity of psychic time, making of the past a past and of the present an unambiguously monolithic, synchronous moment not haunted by any ghosts. The cure for trauma rests upon the assumption that time is linear and that the perception of time in any other form is a pathological delusion. The collectivization of this model in the notion of 'cultures of trauma' similarly implies a dysfunction at the social level: the idea of a wounded society composed of a mass of indistinguishable victims and perpetrators all equally scarred by the violent moment from which they cannot distance themselves (Fassin and Rechtman 2009).

The assumption that the resurgence of the past in the present represents a pathology deploys universally a culturally specific view of temporality as laminar, single-stranded, and unidirectional. The life-worlds explored in this special issue challenge and problematize the premise of a linear flow of time that ineluctably distances and insulates individuals from an ever-receding past. Each of the articles implicitly questions the memory paradigm, moving anthropological research from a focus on memory as traced along a hypostasized singlestranded temporal continuum to exploring chronological models that radically 
question Western post-Enlightenment assumptions regarding the nature of time itself (pace Bloch 2012: 213). Where the past plays the role of an implacable social presence, we can conceive of it not only as remembered but also as immanent. The immanence of the past in the present necessitates a shift from models of memory to a recognition of the presence of the past in everyday life. The post-Ottoman condition is not the memory of the past but its presence: time without duration.

Memory studies have revealed the social dynamics of memorial processes and facilitated the analysis of conflicts over the meaning of the past in terms other than those of an empiricist debate over historical veracity. Studies confined to social memory cannot, however, fully realize the theoretical implications of this departure, which lie in the destabilization of dominant Enlightenment models of time. The field of memory studies always contained within it the cause of its own supervention, the insights it permitted destabilizing the ground upon which it was founded. Rather than redefining what we mean by social or collective memory in order to secure the survival of the paradigm, this special issue moves from the ground cleared by memory studies into new territory in which debate can begin over the nature of social time, that is, the temporalities of culture. The studies included here demonstrate that temporality in the post-Ottoman world marks the site of a battleground disputed by multiple factions in an unresolved conflict, the outcome of which has yet to be determined. It is largely because of the ongoing and urgent relevance of the past to the present in the nation-states of the Balkans, Turkey, and Greece that past, present, and future become mutually juxtaposed and intertwined, particularly following episodes of crisis and political violence. It is to the resulting multi-temporalities of the post-Ottoman world that this issue is devoted.

\section{Ottoman Half-Lives}

If post-Ottomanism does not involve nostalgia for a lost empire, neither does it imply that Ottomanism has been definitively left behind, forgotten, or superseded. Beneath official discourse, Ottoman social formations retain a presence in the grassroots culture and collective consciousness of the nation-states that have replaced the empire. The religious and linguistic minorities and the abandoned villages, places of worship, and cemeteries of the post-Ottoman sphere, as well as the displaced people who recall their ties to these places, attest to the stubborn afterlife of the Ottoman Empire and gain strength in the ethos of uncertainty and exclusion that has made so many post-Ottoman states hostile to their minorities. Post-Ottomanism shares an air de famille with postmodernity and with post-colonialism to the extent that it bears witness to the waning of belief in the modernist certainties of the nation-state project, to a resurgence of fragmentary identities to which the state cannot do justice, and to a growing ethos of divisionism in which the monolithic unities of ethnicity and territory come to be questioned by the cleavages of religion, language, class, and age cohorts and in which awareness of alternative pasts and possible futures become matters 
of popular interest and engagement. This is not to say that post-Ottomanism signals the definitive abandonment of Ottoman identity in the manner that postmodernism and post-colonialism signal a break with modernity or with empire, or that post-Ottomanism implies an unalloyed regressive nostalgia for the Ottoman Empire. Post-Ottomanism is neither revolutionary nor reactionary.

Given that post-Ottomanism does not take the form of a memory of Ottoman identity, what is it? What forms does the presence of the Ottoman past take? What are the implications of the post-Ottoman condition for our analytical models of time and historicity, on the one hand, and of collective memory, on the other? In a sense, experiencing Ottoman identity became possible only after the empire had collapsed, making the status of its erstwhile members problematic and open to question-like Mary Douglas's dirt, everyone was suddenly matter out of place. In the sense that Ottoman identity would come to be known after the end of empire, it was to be known only in its futurity. Forever dependent upon what its erstwhile subjects would later become, Ottoman identity today has no stable core; instead, it operates as a deictic term or, as Dimitrios Theodossopoulos (2006) has said of the concept of 'Turk' in Greece, as a hollow category pointing to the future in its endless demiurgic generation of new meanings. In his essay "Ottoman Half-Lives," Peter Loizos (1999) has shown that for a plethora of groups in the Mediterranean, Ottoman identity emerged as a result of the population movements occasioned by the collapse of the empire. The massacres, forced displacements, and resulting minority status of the displaced groups of refugees created a vivid sense of identity and difference based upon past experience. One of the case studies that Loizos uses is that of Renée Hirschon on the Asia Minor refugees who settled near the port of Athens after the forced exchange of populations. While recognizing that her informants remembered their Muslim neighbors as people with whom they were on good terms, Hirschon (1998) underlines the role played by the violence of displacement in establishing a tissue of collective memories that would bind this impoverished community together for the next three generations. ${ }^{7}$ Dimitris Tziovas (2009: 5) echoes this insight when he identifies a Greek crisis of identity sparked by exile and resulting in a shift from identity through common belonging in locality and space to common belonging in memory and liminality.

To be post-Ottoman in the twentieth century was thus not only to be burdened by the melancholia of forbidden memories of peaceful co-existence, but also to have been victims of political violence, and it was in part through the experience of persecution and displacement that people became aware of themselves as minorities in the new nation-states emerging from the ruins of the empire. Equally conscious of two conflicting and irreconcilable memories of their origins - of a 'cultural intimacy' (Herzfeld 1997) with Ottoman Turks, on the one hand, and of the Turks' alleged inhumanity, on the other-the past of the refugees and of Greeks more generally became disemic, composed of uncomfortably grafted branches whose strange fruit would always be an ambivalent scion of Western, Hellenic identity and of Eastern, Romeic (Byzantine, then Ottoman) memory. The former was publicly lauded but the latter intimately encrypted (Herzfeld 1987, 1997; Theodossopoulos 2006). 
The cauldron of national identities that the sudden collapse of the Ottoman Empire produced has resulted in one of the greatest regional concentrations of studies of collective memory and critical historiography in the social sciences. Reflecting the juxtaposition of past and present at both the popular and the national levels in the twentieth century, Laurie Hart's (1992) work on Christianity, time, and memory in the Eastern Peloponese, Nadia Seremetakis's (1991, 1994) writing on the memorialization of the dead in Inner Mani, and David Sutton's (1998) multi-stranded inquiry into history and memory in Kalymnos all demonstrate the means by which religion, nationalist politics, and memory have been wedded in the ethnography of Greece. In his work on Crete, Michael Herzfeld (1985) describes the manner in which contemporary masculine identity is justified with reference to Ottoman domination and the banditry, theft, and illegality that thrived in the socio-political environments that replaced Ottoman occupation. Herzfeld (1991) also examines the contradictions between bureaucratic models of 'monumental time' - the time of the nation-state-and 'social time', representing a popular 'counter-archaeology', while Daniel Knight (2012a, 2012b, 2015) explores the temporal juxtapositions between the present crisis in Greece and the Ottoman past.

Rey (2008) delineates the ways in which a visionary movement among Asia Minor refugees in Lesbos came to play the role of surrogate memories of repressed, unremembered suffering to which the dreamers' refugee parents were subjected in the cataclysm of the exodus from Anatolia. Apparitions of the oikoumenê, such memories are not condemnatory of an essentialized Turkish barbarian. In a similar fashion, processes of collective dreaming among members of a millenarian Orthodox cult on the Aegean island of Naxos, as Stewart (2012) describes, implicitly questioned the legitimacy of the emergent Greek nation-state. Stewart makes use of the historical paradigm to unearth a century of recurring crises in the mountain village of Kóronos while simultaneously sustaining a critique of the same historical paradigm as a Western construct. Not only is time cyclical according to the vernacular authors of the 'myth-history' that Stewart uncovers, but the apparent linearity of time is itself a Western folk model that has now spread so ubiquitously as to impose itself as a dominant model over alternative conceptions of time.

Leyla Neyzi $(2002,2008)$ has studied the 'forgetting' of Greek origins among Turks of Sabbatean heritage from Salonika and conflicting discourses of the past in Smyrna after what the Greeks call 'the Catastrophe' and Turks 'the Liberation'. ${ }^{8}$ A similar appropriation of history to nationalist ends, as depicted by Neyzi and by Sutton (1998), is noted in Anastasia Karakasidou's (1997) analysis of the 'anti-historicity' of Macedonian neo-Hellenist origin myths. Like Rey, Karakasidou (ibid.: 32, 36) recounts the atemporality of local origin myths in the Macedonian town of her study, which often juxtaposed the prehistoric with the ancient Greek, the Byzantine, and the Ottoman periods, blending myth, legends, and history in the construction of a 'national time'. ' In the same region, Loring Danforth and Riki Van Boeschoten (2012: 35-36) describe the movement of children out of Greek Macedonia during the Greek Civil War as another population displacement that was experienced by the ethnic groups involved 
as a continuation of the conflicts of the Ottoman era. ${ }^{10}$ In Cyprus, Yael NavaroYashin (2012: 152) has recently delineated the resurgence of Ottoman categories in new, unwelcome guises in the phenomenon of ganimet, an Ottoman term for war booty that became overlaid with connotations of loot or plunder after the 1974 partition of the country. The unspoken sense of unease that Turkish Cypriot settlers in Northern Cyprus feel on a daily basis leads Navaro-Yashin to look to their material world and physical surroundings as the source of a political sentiment that is incorporated more than it is verbalized.

Everywhere in the nation-states of the Balkans and the Greek peninsula, the proliferation of references to the Ottoman past and to post-Ottoman state formation points to tears, scars, hauntings, and occluded, doubled, or contested epochs that remain alive today in the social fabric of collective life and in the ideologies of state. Even when these memories or returns do not explicitly reference the Ottoman Empire-for example, when they seem restricted to a narrower, nationalist time frame or to a deeper, classical or prehistoric one (see Knight, this issue) - it is still the case that the collapse of chronological time itself can be located in the demise of the Ottoman Empire and the following sequence of events that that upheaval set in motion for so many people. It is in the collapse of chronological time that we can speak of post-Ottoman identities or temporalities. Like other forms of post-colonialism, the post-Ottoman condition need therefore not refer exclusively to the Ottoman period or to the Ottoman Empire, but more broadly to the sequelae of nation building and nationalisms, to sub- and supra-national identities, and to the loss of a sense of being anchored in linear time that ensues from the multiple catastrophes of state formation: the forced population movements, the massacres, the wars, and the polarization to the violent extremes of the political spectrum that Bruce Kapferer ([1988] 2011) has chronicled for Sri Lanka and Australia.

But where Kapferer reveals the means by which the distant mythical past can fall prey to the nationalist manipulations of radical politicians and clergy, this special issue records the half-lives of melancholia for lost co-existence emergent in collective affects that bear witness to mass violence from the perspective of victims rather than perpetrators. ${ }^{11}$ And yet where does Blanchot's (1995: 42) entreaty with reference to the Shoah to watch over 'absent meaning' fade into irredentist or xenophobic nationalism? Like the complexity of time, the indeterminacy of affect allows a community to conceal the sword of revanchism beneath the cloak of victimhood. ${ }^{12}$ So it was that the memory of the fall of Constantinople in 1453 (an official memory propagated by the Orthodox Church and then by successive state entities in Greece and the Balkans) kept open a wound that would become infected with the tragedy-in-waiting of the irredentist Great Idea, the Greco-Turkish War of 1919-1922 and the final demise of that ill-fated project in the Great Fire of Smyrna in September 1922 (Herzfeld 1986). Smyrna-city of infidels (giaour Izmir) to the Kemalist insurgents who reduced the wooden metropolis to ashes, seat of a violated Hellenic civilization to the invading Greek army-had in fact been a wellspring of social effervescence and tolerance to its plural inhabitants. Like Alexandria, Constantinople, and Beirut, it had ranked among the great cosmopolitan centers of the world (Kirli 2005; Mansel 2010; Neyzi 2008). 


\section{The Immanence of the Past: Post-Ottoman Topologies and the Paradox of Co-existence}

Hirsch and Stewart's (2005) and Stewart's (2012, this issue) theory of historicity makes explicit what the ethnographic evidence adumbrates: that the unilinear model of historical time is a modern Western construct that is not applicable in much of popular Western culture, let alone in non-Western contexts. ${ }^{13}$ In making a distinction between modernist or objectivist Western models of chronological time, on the one hand, and non-linear, social, or subjective formations of time, on the other, it is important to point out that the articles in this special issue do not draw a Manichaean or neo-evolutionary opposition between Rankean Western history and post-Ottoman memory. While the centrality of Pierre Nora's contribution to the field of collective memory is not to be disputed, the point of this project is not to rehearse Nora's (1992) dichotomy between societies with (written, authoritative, empirical) history and those with (subjective, mythical, pre-Enlightenment) memory. ${ }^{14}$ Herzfeld's (1991) description of 'monumental time' underlines that Enlightenment historical chronology can be appropriated as a discourse of state and used in a politics of distinction that has little to do with scientific advancement and rather more to do with the imposition of power. The point, then, is not to revive the Geertzian opposition between societies beholden to cyclical time versus those graced with linear time (Geertz 1966, 1973; cf. Bloch 1977; Howe 1981) or to repeat Leach's (1961) dichotomy between a modern, Western grasp of linear chronology and a primitive belief in 'alternating time', still less to promote the LéviStraussian distinction between 'hot' and 'cold' societies (Charbonnier 1969; Lévi-Strauss 1952, 1969; cf. Gell 1992: 23-29). The articles in this issue move beyond these dichotomies, recognizing that people the world over live with multiple registers of time: linear and cyclical, modernist and anachronistic, empiricist and subjective/affective, collective and individual, deep and diurnal.

This intention of this special issue is not to explore which societies have linear time and which have 'ethnic' or 'cultural' time; rather, the goal is to uncover the social and political conditions that interrupt, complexify, or problematize the unitary or laminar flow of time in any society. The focus is not on time per se, but on political violence and on the effects on memory and the passage of time that exposure to such violence begets. The post-Ottoman condition-the effects on time brought about by large-scale violence, political transformation, and the forced movement of peoples-refers to the looping effects of alternative temporalities that flow from different sources against the current of the national narrative. These looping effects and turbulences are part of the state in late modernity. They trace the global dynamic of post-Ottomanism in the states that emerged from the Ottoman Empire but can also be viewed as a latent force to which all states are susceptible.

Violence and crisis potentially affect the peoples residing in or having been banished from any nation-state constructed from the violent reduction of once pluralist and cosmopolitan societies into putatively homogeneous groups that have been given a sense of common purpose through the invention of a manifest 
destiny. The prime exemplar of post-Ottoman society outside the Balkans is the irremediably melancholy sight of the swaths of Europe that lost their Jewish populations in World War II. The twentieth century is forever marked in our memory by its desiccation and splintering of human identities within ever narrower and stricter ethnic, religious, or racial boundaries and the insistence that these were worthy causes for mass exile and industrial murder. But the postOttoman condition exists not simply in the half-lives of fascist nationalism and the untold violence wrought on once plural communities; it also bears witness to the enduring presence of the time before the Fall (re)constructed after the Exodus. Joëlle Bahloul's (1992) description of her family's exile from Algeria due to their Jewish heritage is therefore a tale of post-Ottomanism-a tragic inversion of the exodus following the Spanish Reconquista in contemporary Sephardi Jewish memory described by Lévy and Olazabal (2015). So too is the plight of the Greeks of Alexandria under Nasser, of the Indians of Uganda under Idi Amin, of the Tamils of Sri Lanka under state Buddhism (Tambiah 1992), of the Muslims of India at the time of partition, and of the Rohingya Muslims of western Burma in the boat crisis now unfolding in the Indian Ocean. In all of these cases, the loss of a plural space-for both the rejected minority and the remaining majority-is replaced with alienation from an essentialized and monolithic one.

The melancholic but insistent immanence of plural pasts in a monolithic present calls for a new framework that will replace the unilinear chronology still implicit in memory studies with multiple and complex chronologies of transformation and flux, of Brownian motion and of chaos. The transition from memory to multi-temporalities would mirror the transition from Euclidian geometry to topology in the study of shape and surface. Just as the shift to topology in the sciences allowed for the study of space not as fixed but in movement and distortion, so too new socio-cultural models of time might allow us to account more fully for cultural models and experiences of the nonlinear flow of time, its doubling back and enfolding in eddies and whirlpools, and its apparent differential rates of flow as some critical events become everpresent while others fade away from public consciousness. ${ }^{15}$

In geometric terminology, some shapes are homeomorphic: they are not in outward appearance identical or even similar, but can nevertheless distort into perfect juxtapositions of each other without the need for any incisions or additions. Moreover, there are qualities of certain masses that do not depend upon their shape and of certain sets that do not depend upon the sizes of their parts. Such masses or sets can transform topologically without affecting the qualities inherent in them. In this manner, topological geometry, or the study of topos (space/place), asks not what is peculiar to a given shape, but what are the potentialities of a given mass or set in all of its possible distortions. Just as topology examines the qualities of space in all of its dimensions and in flux and transformation, this special issue analyzes the post-Ottoman condition not only as topos, but also as chronos, accounting for the effects on time and history, as well as on space and place, of the transformations and continuities that spacetime undergoes in the social or national body. We have all experienced, at both 
a personal and a collective level, how some critical events, such as the birth of Christ (year zero) and of the First French Republic (an zéro), become everpresent, all-enveloping, or sempiternal, remaining close and everywhere, while others fade away from public consciousness, becoming distant and placeless.

This issue outlines the homeomorphism of events in time, highlighting the transformations and juxtapositions that collective memory fashions out of chronologically distant events. It delineates a topology of time-space instead of space alone: a chrono-topology or chronotope. In Bakhtin's (1981) analysis, the chronotope is applied to the form of time typical to a literary genre, where time and place intersect as dimensions of one another (as in Einstein's theory of relativity, from which he borrows the term). Exploring ancient Greek literature, Bakhtin was interested in the literary conjunction of people to place (as expressed in the classical model of the oikoumenê). However, in post-Ottoman topologies, it is time rather than place that plays the leading role in the conceptual pairing, with place for many of the contributions to this issue having become problematic through its loss, absence, or destruction. Forever placeless, the post-Ottoman subject lives in time and is at home only through the folds, reversals, and recursivities that culture affords to chronology. The multiple potential of space in geometry exemplifies the transformations of time in post-Ottoman culture and society.

Taking his lead from the analytic philosopher D. H. Mellor (1981), Alfred Gell (1992) makes a concerted attempt to look at time in anthropology, distinguishing between 'objective' (B-series) and 'subjective' (A-series) time. In his argument, B-series time (static, untensed, quantitative) is not accessible to human perception and can only be grasped through A-series time-the qualitative experience of chronology and tenses (ibid.: 150; cf. Hodges 2008). Albeit an anthropologist, Gell unaccountably fails to examine critically the claims to scientific objectivity on Mellor's part or to examine the implications for ethnographic insight of his own presumption that only 'objective' time-imperceptible to all, by Gell's own admission-should be afforded reality status. Accordingly, Gell (1992: 318) does not consider Bergson's philosophy of time, which places more importance on human experience, dismissing Bergson out of hand as "a prime A-Theorist." In counterpoint to Gell, Bergson ([1896] 1939) views B-series time as an intellectual construct with no lived reality. Supposedly empirical, B-series time is in fact a mathematical abstraction.

The time we live, Bergson ([1896] 1939: 232; my trans.) insists, cannot be "that impersonal and homogeneous duration, the same for all things and all people, which would flow onward, indifferent and void, external to all that endures." ${ }^{16}$ Such a time, if it did exist, would be true but trivial, devoid as it is of human content. "In reality," Bergson concludes, "there is no one rhythm of duration" (ibid.). Bergson's argument is empiricist but also phenomenological. The fullness of all time lies beyond the senses just as the atomic dimension of nature, which was being discovered during Bergson's lifetime, is also invisible to us. Different forms of perception-were they per impossibile to exist-would be able to discern multiple temporalities co-existing in any given body of matter. In that sense, Bergson argues, multiple temporalities are not abstract models but physical realities. 
Deleuze (1966) retraces Bergson's admonition that the past returns to us as a means of acting in the present. He points out that the past in its undivided entirety has not ceased to be, but is. The present, by contrast, is not but, at every instant, was. In this sense, the present is past and the past present. For Deleuze, the past and the present are not successive moments but two elements that co-exist: "Bergsonian duration is, in the end, ... defined less by succession than by co-existence” (ibid.: 56; my trans.). Thus, Deleuze sees a first paradox as the "contemporaneity of the past with the present it has been" (1968: 111; orig. italics; my trans.). The second paradox is that of co-existence: "If each past is contemporaneous with the present it has been, all the past co-exists with the new present in relation to which it is now past" (ibid.). Deleuze's reworking of Bergson's theory of durée offers a radical philosophical underpinning for achronological, non-linear models of time and memory. ${ }^{17}$

In this special issue, we do not pronounce on what the ontological nature of time might be, but ask how time is experienced in human sociality, cosmology, and practice. ${ }^{18}$ The collective sense of the fullness of time has only relatively recently disappeared from Western culture, occluded by the dominant discourse of Western historicism and its unilinear chronology - a discourse that has deemed haunting an anachronism, made the perception of ghosts and states of possession pathologies, demoted divine vision to hallucination, and turned the miracle of the Eucharist (the obliteration of the time separating us from the Last Supper) into a disenchanted re-enactment for the enchanted minority. Despite the imperial dominion of the dominant model of unilinear time across the globe, the peoples of the nation-states of what was once the Ottoman Empire live with plural temporal registers. Born of collective suffering, post-Ottoman time is the time of collective consciousness. It is social time, and, like Bergsonian time, it does not flow evenly or irreversibly. ${ }^{19}$ Bergson's and Deleuze's models of temporality describe time generically. In this issue, we examine how the experience of durée is affected by rapid social change, political violence, and crisis. It is not all past time that remains present, but certain specific episodes of the past that appear to return or to become immanent in culture and experience.

Michel Serres's (1990) focus in an interview with Bruno Latour on the temporal effects of political violence underscores this point. Reflecting on his childhood in German-occupied France, Serres describes himself as still hungry with the famine that he survived as a child and depicts time as chaotic, nonlaminar, and polychronic precisely because of the violence of history. While not all of Serres's childhood appears present to him, the atrocities committed by the Axis and Allied forces come to seem, in their temporal dislocation, as at once futuristic and archaic. Such memories-together with others from the war and its aftermath that he did not witness directly but by which he was equally wounded in his youth-live on in his experience today because of their atrocity, and they return to him at key moments in history that seem to replay past events in their brutality. ${ }^{20}$ For Serres, it is the indelible stain of evil and suffering that causes the wrinkles, tears, scars, and deformations in time that call for a topological analysis of human temporalities. 
The articles in this special issue explore the topological dimensions of time not sui generis or ontologically, but in relation to specific case studies of human experience and suffering. Whether this be the collective anxiety triggered by the Greek sovereign debt crisis (Knight), the 'uncanny' returns caused by the Great Depression or the civil war (Stewart), or the longer-term effects on Asia Minor refugees of political violence and displacement (Rey), anthropology needs to do justice to the social reality of temporal collapse and looping that violence, exile, crisis, mourning, and precariousness engender. Even when the past seems safely dead and buried, as the civil war appears to be in the Greek village that Gefou-Madianou describes, it can burst through the surface of everyday calm to revive communal conflicts. Alternatively, the past can remain present and open to interpretation in the aporias of media broadcasting (Papailias). Regimes of denial and amnesia may likewise be brushed aside by contemporary events, as in Turkey (von Bieberstein). War remembered at first hand has an enduring existence in the daily lives of survivors in Bosnia-Herzegovina, but, through prayer, it also excavates collective memories of past wars from the Ottoman period (Henig). What is life in the aftermath of conflict if not a deracination? Uprooted from one's home by the threat of imminent violence, one returns to a place-if one returns-that no longer exists. The returned refugee remains off-balance, one foot in the past in a land that is both 'here' and 'nowhere'. Hart examines this predicament in her comparison of a border zone in northwest Greek Macedonia with Bosnia. In both cases, the return in the aftermath of violence begets an indeterminacy in space and time that bespeaks the fractured social ties of people displaced by war: space without places, time without duration.

\section{Acknowledgments}

This special issue-dedicated to the memory of Peter Loizos-emerges from a workshop held at the British School at Athens on 19-21 May 2013 in which Peter had been planning to participate. The event was funded by the Economic and Social Research Council (ESRC) as part of a two-year fellowship, "Remembering Absence: Catastrophe, Displacement and Identity among Chiots and the Chiot Diaspora," for which Peter had acted as my mentor. I thank the ESRC and the British School at Athens-Catherine Morgan in particular-for making the workshop and the resulting special issue of articles possible. I additionally thank Charles Stewart for co-organizing the workshop with me; Penelope Papailias, Eleana Yalouri, and Eftihia Voutira for their invaluable input as discussants at the event; and Eric Hirsch, Dimitrios Theodossopoulos, and two anonymous reviewers for very helpful comments on an earlier draft of this introduction. 
Nicolas Argenti is a Senior Lecturer in Anthropology at Brunel University. He has focused his research on Cameroon since the early 1990s and on Greece since 2010. A two-year ESRC research fellowship on the Aegean island of Chios, "Remembering Absence: Catastrophe, Displacement and Identity among Chiots and the Chiot Diaspora," explored collective memories of political violence dating back to the nineteenth century and their contemporary resurgence in the context of the Greek sovereign debt crisis. He is the author of The Intestines of the State: Youth, Violence, and Belated Histories in the Cameroon Grassfields (2007) and coeditor of several collections, including (with Katharina Schramm) Remembering Violence: Anthropological Perspectives on Intergenerational Transmission (2010).

\section{Notes}

1. Cf. Philip Mansel (2010) on the great Ottoman trading cities and Humphrey and Skvirskaja (2013) on post-cosmopolitan cities. For a critique of modern visions of past intercommunal harmony in Istanbul, see Amy Mills $(2006,2010)$.

2. As Green (2010: 267) says of the exchange of populations between Greece and Turkey: "Something remained of that earlier logic of border-ness: the decision about who was to be moved from Turkey to Greece and vice versa was based on the key Ottoman distinction of religious affiliation, which had in the past been used to organize people into millets - the administrative, legal and tax groupings of the Ottoman regime. The national difference between contemporary Greece and Turkey thus became integrally related to the difference between Orthodox Christian and Muslim. An extended relation between earlier and later forms of border-ness was thus embedded within the apparent complete break between past and present." On the ongoing shared used of religious sites by Muslims and Christians to which Green refers in her article, see also Albera and Couroucli (2012).

3. For a critique of the Ottoman Empire as a despotic system, see Barkey (2008).

4. After the fall of Constantinople, the priests and hierarchy of the Byzantine Empire debated whether the Muslim forces had been sent by God to protect the Orthodox Christians from the worse scourge of the Catholic armies threatening the empire from the West. Another Greek historian, Makraios, had earlier identified not the Turks but the Catholics as "cruel and bloodthirsty wolves of the west" (cited in Ware 1964: 79). The eighteenth-century Chiot Orthodox theologian Eustratios Argenti likewise aimed all of his polemical writing at the papacy and not at Islam (ibid.).

5. The social geographer Augustin Berque (1996, 2009), son of Jacques Berque, resurrects the term to refer to humanity in relation to its lived space in a phenomenological exploration of Heideggerian dwelling.

6. For more detailed studies in this field, see Alexander (2012), Ashplant et al. (2000), Cohen (2001), Connerton $(1989,2011)$, Das et al. (2000, 2001), Erickson (1991), Eyerman (2001), Felman and Laub (1992), Forty and Küchler (1999), Kleinman et al. (1997), LaCapra (2001), Laub (1991), Lyotard (1990), Olick and Robbins (1998), Olivier (2008), Passerini (2005), Radstone (2000), Ricoeur (2000: 95), Robben and Suárez-Orozco (2000), Sluka (2000), and Van Boeschoten (2003).

7. Eftihia Voutira (2003) and Vasso Stelaku (2003) note the centrality of memory and commemoration in Greek refugee ethno-genesis and Eastern Christianity, respectively. 
8. Cf. Kirli (2005) on Turkish amnesia regarding the 1922 burning of Smyrna.

9. Sutton (1998: 123-145) also notes the conflations of time in Kalymnos, in particular, the deep time of biblical stories with revolutionary/nationalist ideologies through the union of church and state. Cf. Herzfeld's (1991) and Papailias's (2005) studies of the protracted and polarized political struggle over history in Greece.

10. Seen by outsiders as a clash between communist and right-wing Greek factions, the conflict was experienced in northern Greece as a complex struggle involving Macedonians with Slav origins and others with ethnic Greek national identities. Nominally on the same side of the conflict, they were nonetheless locked in opposition to one another. In this way, the factions involved in the Greek Civil War of the 1940s had their origins in the collapse of the Ottoman Empire 30 years before. The Ottoman Empire also cast a shadow over the civil war as refugee children taken by communists over the border into Yugoslavia were referred to as victims of a new paidomazoma, the Ottoman practice of collecting Christian children for conversion and conscription as janissaries in the sultan's forces. See Hart (2012) and Karakasidou (1997).

11. Allen Feldman's (1991) analysis of political terror in Northern Ireland likewise demonstrates that chronological narratives of violence are replaced with intertwined, relational narratives. Jennifer Cole (2001) similarly speaks of 'layered memories' in her study of the colonial legacy in Madagascar. Marita Sturken's (1997) work on the 'tangled memories' of the Vietnam War in the United States argues that memories of war are not reducible to one authoritative version of events.

12. Derrida (1986: 56) makes this point in his exploration of the shibboleth in Paul Celan's work.

13. Hirsch and Stewart (2005: 264) argue that the claims to disinterested objectivity of history as a science arose as recently as the nineteenth century in a work of Leopold von Ranke (1824). Despite gaining ascendancy in popular culture, however, Rankean empiricism was critiqued by Heidegger ([1927] 2010), whose entire opus Being and Time can be seen as a rejection of Ranke's position. In it, Heidegger quotes Yorck's 1894 letter to Dilthey dismissing Ranke as "a great ocularist, for whom things that have vanished can never become realities" (ibid.: 380).

14. For critiques of Nora, see Argenti and Schramm (2010) and Sturken (1997).

15. Our use of topology in this special issue therefore differs from that set out by Artemis Leontis (1995) in her Topographies of Hellenism, in which she names topology the study of topography, and explicitly distances the term from its mathematical applications while emphasizing its geographical rather than temporal dimensions.

16. Walter Benjamin (1950: chap. 17; my trans.) picks up on this aphorism in his final work, "Über den Begriff der Geschichte" (On the Concept of History), where "historicism ... has no theoretical armature ... it mobilizes a mass of facts in order to fill up a homogeneous and empty time."

17. For a masterly overview of theories of time in anthropology, see Matt Hodges (2008).

18. At the time that Bergson was writing, Einstein's theories had yet to be accepted by the scientific community. We can look back with hindsight at Bakhtin's work as having been inspired by Einstein's theory, which became widely accepted, while Deleuze's work was based upon Bergson's philosophy, the scientific basis of which came to be rejected. From the perspective of the elaboration of a theory of cultural time, however, the scientific status of the theories that Bergson, Deleuze, and Bakhtin used is of secondary importance: these were exemplars allowing them to conceive of models of time beyond the dominant models.

19. In this sense we can state, despite Gell and Mellor, that for Charlotte Delbo (1970), the writer and concentration camp survivor, the camp was not a 'memory' but a presence that doggedly accompanied her everywhere and always and that can be 
understood, beyond the pathological effect of traumatic recall, as the doubled temporal reality of suffering.

20. Daniel Knight (2012a) has recently noted the 'cultural proximity' of World War II in today's crisis-ridden plains of central Greece.

\section{References}

Agamben, Giorgio. 1998. Homo Sacer: Sovereign Power and Bare Life. Trans. Daniel Heller-Roazen. Stanford, CA: Stanford University Press.

Albera, Dionigi, and Maria Couroucli, eds. 2012. Sharing Sacred Spaces in the Mediterranean: Christians, Muslims, and Jews at Shrines and Sanctuaries. Bloomington: Indiana University Press.

Alexander, Jeffry C. 2012. Trauma: A Social Theory. Cambridge: Polity Press.

Althusser, Louis. 1972. Politics and History: Montesquieu, Rousseau, Marx. Trans. Ben Brewster. London: Verso.

Angé, Olivia, and David Berliner, eds. 2015. Anthropology and Nostalgia. New York: Berghahn Books.

Argenti, Nicolas. 2007. The Intestines of the State: Youth, Violence, and Belated Histories in the Cameroon Grassfields. Chicago: Chicago University Press.

Argenti, Nicolas. 2016. "Laughter without Borders: Embodied Memory and PanHumanism in a Post-Traumatic Age.” In Broch-Due and Bertelsen 2016, 241-268.

Argenti, Nicolas, and Katharina Schramm. 2010. "Introduction." In Remembering Violence: Anthropological Perspectives on Intergenerational Transmission, ed. Nicolas Argenti and Katharina Schramm, 1-39. New York: Berghahn Books.

Ashplant, T. G., Graham Dawson, and Michael Roper. 2000. "The Politics of War Memory and Commemoration: Contexts, Structures and Dynamics.” In The Politics of War Memory and Commemoration, ed. T. G. Ashplant, Graham Dawson, and Michael Roper, 3-86. London: Routledge.

Bahloul, Joëlle. 1992. La maison de mémoire: Ethnologie d'une demeure judéo-arabe en Algérie (1937-1961). Paris: Métailié.

Bakhtin, Mikhail. 1981. The Dialogic Imagination: Four Essays. Trans. Caryl Emerson and Michael Holquist. Austin: University of Texas Press.

Barkey, Karen. 2008. Empire of Difference: The Ottomans in Comparative Perspective. Cambridge: Cambridge University Press.

Benjamin, Walter. 1950. "Über den Begriff der Geschichte.” Neue Rundschau 61 (3).

Bergson, Henri. (1896) 1939. Matière et mémoire. Paris: Presses Universitaires de France.

Berque, Augustin. 1996. Etre humains sur la terre: Principes d'éthique de l'écoumène. Paris: Gallimard.

Berque, Augustin. 2009. Ecoumène: Introduction à l'étude des milieux humains. Paris: Belin.

Berque, Jacques. 1970. L'Orient second. Paris: Gallimard.

Bissell, William C. 2005. “Engaging Colonial Nostalgia.” Cultural Anthropology 20 (2): 215-248.

Blanchot, Maurice. 1995. The Writing of the Disaster. Trans. Ann Smock. Lincoln: University of Nebraska Press.

Bloch, Maurice. 1977. “The Past and Present in the Present.” Man (n.s.) 12 (2): 278-292. 
Bloch, Maurice. 2012. Anthropology and the Cognitive Challenge. Cambridge: Cambridge University Press.

Braudel, Fernand. (1949) 1972. The Mediterranean and the Mediterranean World in the Age of Philip II. Trans. Siân Reynolds. London: HarperCollins.

Broch-Due, Vigdis. 2016. "Trauma, Violence, Memory: Reflections on the Bodily, the Self, the Sign, and the Social.” In Broch-Due and Bertelsen 2016, 23-58.

Broch-Due, Vigdis, and Bjørn E. Bertelsen, eds. 2016. Violent Reverberations: Global Modalities of Trauma. New York: Palgrave Macmillan.

Brunet, Roger, Robert Ferras, and Hervé Théry. 1992. Les mots de la géographie. Paris: La Documentation Française.

Bryant, Rebecca. 2010. The Past in Pieces: Belonging in the New Cyprus. Philadelphia: University of Pennsylvania Press.

Bryant, Rebecca. 2015. "Nostalgia and the Discovery of Loss: Essentializing the Turkish Cypriot past." In Angé and Berliner 2015, 155-177.

Charbonnier, Georges. 1969. Conversations with Claude Lévi-Strauss. Trans. John Weightman and Doreen Weightman. London: Jonathan Cape.

Clogg, Richard. 1992. A Concise History of Greece. Cambridge: Cambridge University Press.

Cohen, Stanley. 2001. States of Denial: Knowing about Atrocities and Suffering. Cambridge: Polity Press.

Cole, Jennifer. 2001. Forget Colonialism? Sacrifice and the Art of Memory in Madagascar. Berkeley: University of California Press.

Connerton, Paul. 1989. How Societies Remember. Cambridge: Cambridge University Press.

Connerton, Paul. 2011. The Spirit of Mourning: History, Memory and the Body. Cambridge: Cambridge University Press.

Couroucli, Maria. 2012. "Introduction: Sharing Sacred Places-a Mediterranean Tradition." In Albera and Couroucli 2012, 1-9.

Danforth, Loring M., and Riki Van Boeschoten. 2012. Children of the Greek Civil War: Refugees and the Politics of Memory. Chicago: University of Chicago Press.

Das, Veena, Arthur Kleinman, Mamphela Ramphele, and Pamela Reynolds, eds. 2000. Violence and Subjectivity. Berkeley: University of California Press.

Das, Veena, Arthur Kleinman, Margaret Lock, Mamphela Ramphele, and Pamela Reynolds, eds. 2001. Remaking a World: Violence, Social Suffering and Recovery. Berkeley: University of California Press.

Delbo, Charlotte. 1970. Auschwitz et après. 3 vols. Paris: Minuit.

Deleuze, Gilles. 1966. Le bergsonisme. Paris: Presses Universitaires de France.

Deleuze, Gilles. 1968. Différence et répétition. Paris: Presses Universitaires de France.

Derrida, Jacques. 1986. Schibboleth: Pour Paul Celan. Paris: Galilée.

Doumanis, Nicholas. 2013. Before the Nation: Muslim-Christian Coexistence and Its Destruction in Late-Ottoman Anatolia. Oxford: Oxford University Press.

Durkheim, Emile. (1892) 1960. Montesquieu and Rousseau: Forerunners of Sociology. Trans. Ralph Manheim. Ann Arbor: University of Michigan.

Erikson, Kai. 1991. "Notes on Trauma and Community.” American Imago 48 (4): 455-472.

Eyerman, Ron. 2001. Cultural Trauma: Slavery and the Formation of African American Identity. Cambridge: Cambridge University Press.

Fassin, Didier, and Richard Rechtman. 2009. The Empire of Trauma: An Inquiry Into the Condition of Victimhood. Trans. Rachel Gomme. Princeton, NJ: Princeton University Press.

Feldman, Allen. 1991. Formations of Violence: The Narrative of the Body and Political Terror in Northern Ireland. Chicago: University of Chicago Press. 
Felman, Shoshana, and Dori Laub. 1992. Testimony: Crises of Witnessing in Literature, Psychoanalysis, and History. London: Routledge.

Forty, Adrian, and Susanne Küchler, eds. 1999. The Art of Forgetting. Oxford: Berg.

Geertz, Clifford. 1966. Person, Time, and Conduct in Bali: An Essay in Cultural Analysis. Southeast Asia Studies, Cultural Report Series No. 14. New Haven, CT: Yale University Press.

Geertz, Clifford. 1973. The Interpretation of Cultures: Selected Essays. New York: Basic Books.

Gell, Alfred. 1992. The Anthropology of Time: Cultural Constructions of Temporal Maps and Images. Oxford: Berg.

Girard, René. 1987. Things Hidden Since the Foundation of the World. Trans. Stephen Bann and Michael Metteer. London: Athlone Press.

Green, Sarah. 2010. "Performing Border in the Aegean: On Relocating Political, Economic and Social Relations." Journal of Cultural Economy 3 (2): 261-278.

Hacking, Ian. 1995. Rewriting the Soul: Multiple Personality and the Sciences of Memory. Princeton, NJ: Princeton University Press.

Halbwachs, Maurice. 1992. On Collective Memory. Ed. and trans. Lewis A. Coser. Chicago: University of Chicago Press. Originally published in French in 1941 and 1952.

Hart, Laurie. 1992. Time, Religion and Religious Experience in Rural Greece. Lanham, MD: Rowman \& Littlefield.

Hart, Laurie. 2012. "Pictures at a Transboundary Basilica." Center for Hellenic Studies, Harvard University. http://chs.harvard.edu/CHS/article/display/4791 (accessed 1 June 2016).

Heidegger, Martin. (1927) 2010. Being and Time. Trans. Joan Stambaugh. Albany: State University of New York.

Herzfeld, Michael. 1985. The Poetics of Manhood: Contest and Identity in a Cretan Mountain Village. Princeton, NJ: Princeton University Press.

Herzfeld, Michael. 1986. Ours Once More: Folklore, Ideology, and the Making of Modern Greece. New York: Pella.

Herzfeld, Michael. 1987. Anthropology Through the Looking-Glass: Critical Ethnography in the Margins of Europe. Cambridge: Cambridge University Press.

Herzfeld, Michael. 1991. A Place in History: Social and Monumental Time in a Cretan Town. Princeton, NJ: Princeton University Press.

Herzfeld, Michael. 1997. Cultural Intimacy: Social Poetics in the Nation-State. New York: Routledge.

Hirsch, Eric, and Charles Stewart. 2005. "Introduction: Ethnographies of Historicity." History and Anthropology 16 (3): 261-274.

Hirschon, Renée. 1998. Heirs of the Greek Catastrophe: The Social Life of Asia Minor Refugees in Piraeus. New York: Berghahn Books.

Hirschon, Renée, ed. 2003. Crossing the Aegean: An Appraisal of the 1923 Compulsory Population Exchange Between Greece and Turkey. New York: Berghahn Books.

Hirschon, Renée. 2007. "Knowledge of Diversity: Towards a More Differentiated Set of 'Greek' Perceptions of 'Turks.'” In When Greeks Think about Turks: The View from Anthropology, ed. Dimitris Theodossopoulos, 61-78. London: Routledge.

Hodges, Matt. 2008. "Rethinking Time's Arrow: Bergson, Deleuze and the Anthropology of Time.” Anthropological Theory 8 (4): 399-429.

Houston, Christopher. 2015. "Politicizing Place Perception: A Phenomenology of Urban Activism in Istanbul." Journal of the Royal Anthropological Institute 21 (4): 720-738.

Howe, Leopold E. A. 1981. "The Social Determination of Knowledge: Maurice Bloch and Balinese Time.” Man (n.s.) 16 (2): 220-234. 
Humphrey, Caroline, and Vera Skvirskaja, eds. 2013. Post-Cosmopolitan Cities: Explorations of Urban Coexistence. New York: Berghahn Books.

Ingold, Tim. 1993. "The Temporality of the Landscape." World Archaeology 25 (2): 152-174.

Kapferer, Bruce. (1988) 2011. Legends of People, Myths of State: Violence, Intolerance, and Political Culture in Sri Lanka and Australia. Rev. ed. New York: Berghahn Books.

Karakasidou, Anastasia. 1997. Fields of Wheat, Hills of Blood: Passages to Nationhood in Greek Macedonia, 1870-1990. Chicago: University of Chicago Press.

Kirli, Biray Koluoglu. 2005. "Forgetting the Smyrna Fire.” History Workshop Journal 60 (1): 25-44.

Kleinman, Arthur, Veena Das, and Margaret Lock, eds. 1997. Social Suffering. Berkeley: University of California Press.

Knight, Daniel M. 2012a. "Cultural Proximity: Crisis, Time and Social Memory in Central Greece.” History and Anthropology 23 (3): 349-374.

Knight, Daniel M. 2012b. "Turn of the Screw: Narratives of History and Economy in the Greek Crisis." Journal of Mediterranean Studies 21 (1): 53-76.

Knight, Daniel M. 2015. History, Time, and Economic Crisis in Central Greece. New York: Palgrave Macmillan.

Kopytoff, Igor. 1981. "Aghem Ethnogenesis and the Grassfields Ecumene." In Contributions de la recherche ethnologique à l'histoire des civilisations du Cameroun, vol. 2, ed. Claude Tardits, 371-381. Paris: CNRS.

Kroeber, A. L. 1946. "The Ancient Oikoumenê as an Historic Culture Aggregate.” Journal of the Royal Anthropological Institute of Great Britain and Ireland 75 (1-2): 9-20.

LaCapra, Dominick. 2001. Writing History, Writing Trauma. Baltimore: Johns Hopkins University Press.

Laub, Dori. 1991. "Truth and Testimony: The Process and the Struggle.” American Imago 48 (1): 75-91.

Leach, Edmund. 1961. Rethinking Anthropology. London: Athlone Press.

Leontis, Artemis. 1995. Topographies of Hellenism: Mapping the Homeland. Ithaca, NY: Cornell University Press.

Lévi-Strauss, Claude. 1952. Race et histoire. Paris: UNESCO.

Lévi-Strauss, Claude. 1969. The Elementary Structures of Kinship. Boston: Beacon Press.

Lévy, Joseph J., and Inaki Olazabal. 2015. "The Key from (to) Sefarad: Nostalgia for a Lost Country.” In Angé and Berliner 2015, 139-154.

Lewis, Sara E. 2013. "Trauma and the Making of Flexible Minds in the Tibetan Exile Community." Ethos 41 (3): 313-336.

Leys, Ruth. 2000. Trauma: A Genealogy. Chicago: University of Chicago Press.

Loizos, Peter. 1999. "Ottoman Half-Lives: Long-Term Perspectives on Particular Forced Migrations.” Journal of Refugee Studies 12 (3): 237-263.

Lyotard, Jean-François. 1990. Heidegger and "the Jews." Trans. Andreas Michel and Mark S. Roberts. Minneapolis: University of Minnesota Press.

Mansel, Philip. 2010. Levant: Splendour and Catastrophe on the Mediterranean. London: John Murray.

Mellor, D. H. 1981. Real Time. Cambridge: Cambridge University Press.

Merleau-Ponty, Maurice. 1962. The Phenomenology of Perception. Trans. Colin Smith. London: Routledge \& Kegan Paul.

Mills, Amy. 2006. "Boundaries of the Nation in the Space of the Urban: Landscape and Social Memory in Istanbul.” Cultural Geographies 13 (3): 367-394.

Mills, Amy. 2010. Streets of Memory: Landscape, Tolerance, and National Identity in Istanbul. Athens: University of Georgia Press. 
Mintz, Sidney W. 1996. "Enduring Substances, Trying Theories: The Caribbean Region as Oikoumenê." Journal of the Royal Anthropological Institute 2 (2): 289-311.

Montesquieu, Charles-Louis de Secondat. (1721) 1973. Persian Letters. Trans. and ed. C. J. Betts. Harmondsworth: Penguin Books.

Montesquieu, Charles-Louis de Secondat. (1748) 1989. The Spirit of the Laws. Trans. and ed. Anne M. Cohler, Basia C. Miller, and Harold S. Stone. Cambridge: Cambridge University Press.

Navaro-Yashin, Yael. 2012. The Make-Believe Space: Affective Geography in a Postwar Polity. Durham, NC: Duke University Press.

Neyzi, Leyla. 2002. "Remembering to Forget: Sabbateanism, National Identity, and Subjectivity in Turkey." Comparative Studies in Society and History 44 (1): 137-158.

Neyzi, Leyla. 2008. "Remembering Smyrna/Izmir: Shared History, Shared Trauma." History \& Memory 20 (2): 106-127.

Nora, Pierre. 1992. "General Introduction: Between Memory and History." In Realms of Memory: Rethinking the French Past, vol. 1, ed. Lawrence D. Kritzman; trans. Arthur Goldhammer, 1-21. New York: Columbia University Press.

Olick, Jeffrey K., and Joyce Robbins. 1998. "Social Memory Studies: From 'Collective Memory' to the Historical Sociology of Mnemonic Practices." Annual Review of Sociology 24: 105-140.

Olivier, Laurent. 2008. Le sombre abîme du temps: Mémoire et archéologie. Paris: Seuil.

Pamuk, Orhan. 2005. Istanbul: Memories and the City. Trans. Maureen Freely. London: Faber \& Faber.

Papailias, Penelope. 2005. Genres of Recollection: Archival Poetics and Modern Greece. New York: Palgrave Macmillan.

Passerini, Luisa. 2005. "Memories between Silence and Oblivion." In Memory, History, Nation: Contested Pasts, ed. Katharine Hodgkin and Susannah Radstone, 238-254. New Brunswick, NJ: Transaction.

Radstone, Susannah. 2000. "Screening Trauma: Forrest Gump, Film and Memory." In Memory and Methodology, ed. Susannah Radstone, 79-110. Oxford: Berg.

Ranke, Leopold von. 1824. History of the Latin and Teutonic Nations, 1494-1514. London: George Bell \& Sons.

Rey, Séverine. 2008. Des saints nés des rêves: Fabrication de la sainteté et commémoration des néomartyrs à Lesvos (Grèce). Lausanne: Antipodes.

Ricoeur, Paul. 2000. La mémoire, l'histoire, l'oubli. Paris: Seuil.

Robben, Antonius C. G. M., and Marcelo M. Suárez-Orozco, eds. 2000. Cultures under Siege: Collective Violence and Trauma. Cambridge: Cambridge University Press.

Rousseau, Jean-Jacques. 1973. The Social Contract and The Discourses. Trans. G. D. H. Cole. London: Everyman.

Sahlins, Marshall. 1972. Stone Age Economics. London: Tavistock.

Seremetakis, C. Nadia. 1991. The Last Word: Women, Death, and Divination in Inner Mani. Chicago: University of Chicago Press.

Seremetakis, C. Nadia, ed. 1994. The Senses Still: Perception and Memory as Material Culture in Modernity. Chicago: University of Chicago Press.

Serres, Michel, with Bruno Latour. 1995. Conversations on Science, Culture, and Time. Trans. Roxanne Lapidus. Ann Arbor: University of Michigan Press.

Sluka, Jeffrey A., ed. 2000. Death Squad: The Anthropology of State Terror. Philadelphia: University of Pennsylvania Press.

Smyrnelis, Marie-Carmen. 2005. Une société hors de soi: Identités et relations sociales à Smyrne aux XVIIIe et XIXe siècles. Paris: Peeters.

Stelaku, Vasso. 2003. "Space, Place and Identity: Memory and Religion in Two Cappadocian Greek Settlements.” In Hirschon 2003, 179-192. 
Stewart, Charles. 2012. Dreaming and Historical Consciousness in Island Greece. Cambridge, MA: Harvard University Press.

Stoler, Ann L. 2008. "Imperial Debris: Reflections on Ruins and Ruination." Cultural Anthropology 23 (2): 191-219.

Sturken, Marita. 1997. Tangled Memories: The Vietnam War, the AIDS Epidemic, and the Politics of Remembering. Berkeley: University of California Press.

Sutton, David E. 1998. Memories Cast in Stone: The Relevance of the Past in Everyday Life. Oxford: Berg.

Tambiah, Stanley J. 1992. Buddhism Betrayed? Religion, Politics, and Violence in Sri Lanka. Chicago: University of Chicago Press.

Theodossopoulos, Dimitrios. 2006. "Introduction: The 'Turks' in the Imagination of the Greeks." South European Society and Politics 11 (1): 1-32.

Todorova, Maria, ed. 2004. Balkan Identities: Nation and Memory. New York: New York University Press.

Todorova, Maria. 2009. Imagining the Balkans. Oxford: Oxford University Press.

Toynbee, Arnold. 1922. The Western Question in Greece and Turkey: A Study in the Contact of Civilisations. London: Constable.

Tziovas, Dimitris, ed. 2003. Greece and the Balkans: Identities, Perceptions and Cultural Encounters since the Enlightenment. Aldershot: Ashgate.

Tziovas, Dimitris. 2009. "Introduction." In Greek Diaspora and Migration since 1700: Society, Politics, and Culture, ed. Dimitris Tziovas, 1-14. Aldershot: Ashgate.

Van Boeschoten, Riki. 2003. "The Trauma of War Rape: A Comparative View on the Bosnian Conflict and the Greek Civil War.” History and Anthropology 14 (1): 41-54.

Voutira, Eftihia. 2003. "When Greeks Meet Other Greeks: Settlement Policy Issues in the Contemporary Greek Context.” In Hirschon 2003, 145-159.

Ware, Timothy [Bishop Kallistos]. 1964. Eustratios Argenti: A Study of the Greek Church under Turkish Rule. Oxford: Clarendon Press.

Warnier, Jean-Pierre. 1985. Echanges, développement et hiérarchies dans le Bamenda pré-colonial (Cameroun). Wiesbaden: Franz Steiner Verlag.

Warnier, Jean-Pierre. 2014. "L’institution monétaire de la royauté en Afrique Centrale." Études Rurales 193: 107-144.

Young, Allan. 1995. The Harmony of Illusions: Inventing Post-Traumatic Stress Disorder. Princeton, NJ: Princeton University Press. 